\title{
Water Pollutants Discharge Permit Systems of the United States and China: A Comparison Using Referential Method
}

\author{
Ye Yuan, Yisong Li \\ School of Law, Hohai University, Nanjing, China \\ Email: yuanye@hhu.edu.cn
}

How to cite this paper: Yuan, Y., \& Li, Y. S. (2020). Water Pollutants Discharge Permit Systems of the United States and China: A Comparison Using Referential Method. Beijing Law Review, 11, 579-601. https://doi.org/10.4236/blr.2020.112035

Received: January 29, 2020

Accepted: May 26, 2020

Published: May 29, 2020

Copyright $\odot 2020$ by author(s) and Scientific Research Publishing Inc. This work is licensed under the Creative Commons Attribution International License (CC BY 4.0).

http://creativecommons.org/licenses/by/4.0/

\begin{abstract}
Using a referential method, a comparative study is carried out on the USA Clean Water Act (CWA) and the PRC Water Pollution Prevention and Control Law (WPPCL). Both laws employ a discharge permit system to achieve their respective environmental goals. The focus of the study is on the comparison of the CWA/National Pollutants Discharge Elimination System and the WPPCL/Water Pollution Discharge Permit system. It is first pointed out that the comparison of environmental laws is not a "better-law comparison". Instead, an environmental law in one country may be used as reference to examine how an environmental law in another country can be developed and implemented within the respective legal framework. Comparison between the USA CWA/NPDES and the PRC WPPCL/WPDP is made from the perspectives of law objectives, implementation procedures and enforcement actions. Several recommendations are then made to better design and implement the permit system in China, with respect to ethical premise, concrete law, discharge standards and enforcement.
\end{abstract}

\section{Keywords}

Water Pollution Discharge Permit, NPDES, Referential Method

\section{Introduction}

Since the "Reform and Opening-up" in 1978, China has achieved an economic growth at more than $10 \%$ p.a. for more than four decades. But this is accompanied by severe environmental degradation, most clearly seen in air, water and soil pollution. To combat the problem, China has since 1992 substantially upgraded and enriched its environmental protection legal system: Tort Liability 
Law of 2009 has stipulated the liability of environmental polluters and that they must bear the burden of evidence in case of litigation (Article 65-68); Criminal Law of 2011 has added Article 338 which defines crime of severe environmental pollution; Environmental Protection Law (EPL) has been revised and become more strict in January 2015; Civil Procedure Law, which was in 2017 revised, has qualified the State's Procuratorate in its Article 55 with the plaintiff's legal standing equal to the other organizations who are stipulated by the law, to file a lawsuit against the defendant who damages the public interest such as destroying the ecological environment and resource protection, or at least to support the social organizations in the process of litigation.

A key component of China's environmental law system is the Water Pollution Prevention and Control Law (WPPCL) enacted in 1984 and revised in 1996, 2008 and 2017. ${ }^{1}$ But as the WPPCL became more sophisticated over the years, effluent discharge continued to surge, causing nationwide water quality deterioration and notorious pollution accidents. The WPPCL uses the water pollution discharge permit (WPDP) system as a key measure to control point source effluents and empowers the State Council to develop concrete practice regulations for its implementation since 2008 Amendment. ${ }^{2}$ But until now a national-wide effective regulation has never been issued by the central government of China.

As response to the WPPCL, the State Council published in 2011 the "Guidelines for Strengthening the Key Tasks in Environmental Protection", 3 then in 2016 the "Implementation Plan for Controlling Pollutant Discharge Permit System". ${ }^{4}$ Since July 2017, the former Ministry of Environmental Protection (MEP) ${ }^{5}$ and the Ministry of Ecology and Environment of China (MEE) have issued 25 sets of national Technology-based standards for the related industries. And MEE has also issued "Trial Measures for the Administration of Discharge Permits" 6 in 2018 and the "Management Categories for Stationary Pollution Sources" in

${ }^{1}$ The Law of the People's Republic of China on Prevention and Control of Water Pollution was promulgated on 11 May 1984 by the Standing Committee of National People's Congress of China; this Law was amended on 15 May 1996, on 28 Feb 2008 as well as on 27 July 2017.

${ }^{2}$ Article 21 of WPPCL: "Enterprises and institutions and other manufacturers and operators that discharge industrial and medical waste water directly or indirectly into water bodies and other waste waters that can be discharged with permit pursuant to regulations, shall obtain effluents discharge permits; The centralized operating facility of urban sewage shall also obtain a discharge permit. Discharge permits shall specify requirements for the type, concentration, total amount, and destination of pollutants. The specific measures for shall be stipulated by the State Council. It is forbidden for enterprises, institutions and other operators to discharge waste water and sewage specified in the preceding paragraph to water bodies without a permit or in violation of the provisions of the permit."

${ }^{3}$ State Council of China (2011): "State Council's Guidelines for Strengthening the Key Tasks in Environmental Protection”. http://www.gov.cn/zwgk/2011-10/20/content_1974306.htm, last visit 20 May 2015.

${ }^{4}$ State Council of China (2016): "Implementation Plan for Controlling Pollutant Discharge Permit System". https://www.pkulaw.com/, last visit 28 Dec. 2019.

${ }^{5} \mathrm{MEP}$ was founded on 15 Marz 2008 and was replaced by MEE since 2018.

${ }^{6}$ MEE (2018): “Trial Measures for the Administration of Discharge Permits”. https://www.pkulaw.com/, last visit 28 Dec. 2019.

${ }^{7}$ MEE (2019): "Management Catalogue for Discharge Permits of Pollutants Point-sources". https://www.pkulaw.com/, last visit 28 Dec. 2019. 
2019 to concretely define the permit applicants. At the same time, provincial and local governments have developed their own rules for implementing the WPDP system. Due to lack of valid national-wide effective rule, it is difficult to make WPDP become as effective as the legislators planned. Recently, the State Council and the MEE have been alerted that the scattered rule making has aggravated the management difficulties of point sources of discharge. Therefore, the discharge permit in China was developed towards a comprehensive management legal instrument including water, air and soil pollutants discharge, which is based on the issuance of industry-based technology standards.

Earlier than China's water pollution law, the first major US law to address water pollution was the Federal Water Pollution Control Act of 1948. In the summer of 1969, accumulated oil and debris on the surface of the Cuyahoga River in Cleveland, Ohio, caught fire. In the same year, the NBC television network aired a documentary, Who Killed Lake Erie? As a result, growing public awareness and concern for controlling water pollution by the federal government led to sweeping amendments in 1972 (Griffiths et al., 2012), with that the law became commonly known as the Clean Water Act (CWA), ${ }^{8}$ whose objective is to "restore and maintain the chemical, physical, and biological integrity of the Nation's waters", according to CWA Sec. 101 [a]. The CWA employs National Pollutant Discharge Elimination System (NPDES) permit program to control discharges, which made it unlawful to discharge any pollutant from a point source into navigable waters, unless a permit was obtained. ${ }^{9}$

The CWA explains the general definitions in its Section 502. Understanding how each of the key terms such as "pollutant," "point source," and "waters of the United States" have been defined and interpreted by the regulations is the key to define the scope of the NPDES Program. ${ }^{10}$ Discharge of pollutant is defined as any addition of any pollutant to navigable waters from any "point source". ${ }^{11}$ Discharge is characterized as adding pollutants from the outside world to navigable water (Davison, 2005). Under the CWA, pollutant is defined broadly to include not only traditional contaminants, but also solids such as dredged soil, rock, solid waste, sand, and municipal and agricultural waste discharged into water. ${ }^{12}$ The CWA defines navigable waters as all waters of the United States, including the territorial seas, ${ }^{13}$ which are currently used, were used in the past, or may be subject to use in interstate or foreign commerce, including waters that are subject to the ebb and flow of the tide (Kapp, 2014). Furthermore, point sources are defined as "any discernible, confined and discrete conveyance, in${ }^{8}$ History of the Clean Water Act, Available at:

https://www.epa.gov/laws-regulations/history-clean-water-act; Summary of the Clean Water Act, https://www.epa.gov/laws-regulations/summary-clean-water-act.last visit 07 Feb. 2020.

${ }^{9} 33$ U.S.C. $\$ 1311$ (a).

${ }^{10}$ Office of Wastewater Management, Water Permitting 101.

https://www3.epa.gov/npdes/pubs/101pape.pdf, last visit 11 Feb.2020.

${ }^{11} 33$ U.S.C. $\$ 1362(12)(2012)$.

${ }^{12} 33$ U.S.C. $\$ 1362(6)$.

${ }^{13}$ https://www.epa.gov/cwa-404/clean-water-act-section-502-general-definitions, last visit 07 Feb. 2020. 
cluding but not limited to any pipe, ditch, channel, tunnel, conduit, well, discrete fissure, container, rolling stock, concentrated animal feeding operation, or vessel or other floating craft, from which pollutants are or may be discharged..$^{14}$ Factories and sewage treatment plants are two common types of point sources. ${ }^{15}$

The CWA established technology-based effluent standards for specific industry categories and water quality standards for all contaminants in surface waters. ${ }^{16}$ In order to abide by the limitations set by the CWA, industries should treat wastewater prior to disposal in a water body (Vicario \& Ohliger, 2015). Since its implementation, "the NPDES permitting program has been the 'centerpiece' of the CWA and the primary method for enforcing the effluent and water quality standards established by the Environmental Protection Agency and state governments." The NPDES is the CWA's "most effective weapon against pollution," and therefore plays a significant role in water pollution litigation (Mims, 2015). The US permit practice of the past four decades provides China with an important reference. We are thus motivated to compare the US CWA/NPDES and China's WPPCL/WPDP to identify the major pillars of the permit system and to examine the feasibility of an effective permit system in China's legal framework.

\section{Research Methodology: Referential Approach to Environmental Law Comparison}

Comparative law studies the differences and similarities among the different legal systems. A number of disciplines have developed, including comparative constitutional, administrative, civil, commercial, and criminal laws. Also, many studies on environmental law comparison have been published (Griggs, Peck, \& Xue, 2009). While this is now an important part of comparative law studies, well-suited methods are yet to be developed. Zweigert and Koetz suggested that "the basic methodological principle of all comparative law is that of functionality" (Zweigert \& Koetz, 1998). Under this theory, the starting-point of a comparative analysis is not the rules themselves, but the problems they help to solve. So this approach considers that institutions are comparable if they fulfill similar functions in different legal systems. It places the emphasis on the comparison of law in practice (Reimann \& Zimmermann, 2006). In the end, comparative law becomes a "better-law comparison"-the better of several laws is that which fulfills its function better than the others. Functional approach is today a leading theory of comparative law.

The functional approach has been for years the leading strategy for law comparison, but it is not well equipped for comparison of complex laws, for which functionality is no longer the largest common denominator and the prerequisites for the functional method to work often do not exist. In this study, I attempt to use a referential approach to comparison of environmental laws. While the func${ }^{14} 33$ U.S.C. $\$ 1362(14)$.

${ }^{15}$ https://oceanservice.noaa.gov/education/kits/pollution/03pointsource.html, last visit 07 Feb. 2020. ${ }^{16}$ https://www.boem.gov/environment/environmental-assessment/clean-water-act-cwa, last visit 07 Feb. 2020 . 
tional approach uses law functionality to define law comparability, the referential approach does not place its emphasis on this "norm". Instead, it analyzes the histories of a developed and a developing law and the political and social-economic conditions under which the laws are implemented and to identify the verified strengths and weaknesses of the respective laws, in order to improve the developing law.

Junker (2014) provided an in-depth examination of the history of comparative law. He pointed out that "too often, foundational questions such as why one compares and whether comparative law goals are really achievable are ignored. Instead, we jump ahead immediately into the method of how one compares". Junker observed "that while functionalism has come under criticism, a single, new ship sailing forward upon which to fly the flag of comparativism has yet to emerge. The critical legal studies movement criticized functionalism heavily, but has not put forward an agreed-upon replacement".

The functional method, widely used for comparative law studies, may not be well-suited for environmental law comparison because the functionality of the environmental law is subject to the political, social-economic-cultural and technological conditions of the respective countries. The law impacts normally on the environment as a whole, not only on individual cases, but the impacts can only be evaluated over a long period of time. Thus, the functional approach does not qualify for environmental law comparison from the space and time dimension. A "referential approach" is therefore proposed here.

\section{Different Evolution Patterns of Permit Systems in the USA and China}

Both US CWA and China's water pollution law have chosen effluents discharge permit as the leading pollution control instrument to limit the water pollutants discharge through administrative grant, which is pursuant to the technology-based effluent limitation of end-of-pipe and the quality standard of receiving water. The legal philosophy of permit is the discharge of pollutants to water bodies of respective countries shall not be a right. The public resources can only be used for waste disposal when a permit has been obtained and the effluent limitations written by the permit are to be complied. ${ }^{17}$ However, the two countries own their different legal patterns with regard to sewage permit.

\subsection{Legal Pattern of US Permit}

The most significant earlier water pollution control law in the USA was the 1948 FWPCA $^{18}$ which depended on the states to establish their own water quality standards. In that Act, the free use of waters was presumed. The 1965 Water Quality Act $^{19}$ required all states to establish water quality standards and meas-

\footnotetext{
${ }^{17}$ Office of Wastewater Management: Water Permitting 101, Available at: https://www3.epa.gov/npdes/pubs/101pape.pdf, last visit 14 Feb.2020.

${ }^{18} 33$ U.S.C. $\$ \$ 1251-1376$ : The Federal Water Pollution Control Act of 1948. 30 Jun 1948; Ch. 758; P.L. 845, 62 Stat. 1155.

${ }^{19}$ U.S.C. (1965) The Water Quality Act.
} 
ures to achieve the standards. In spite of the efforts, the water pollution in the USA reached epic proportions by the early 1970s (Andreen, 2008). In 1972, the USA Congress enacted the Clean Water Act (CWA) to control water pollution with federal and state combined efforts. The objective of the CWA is to restore and maintain the integrity of the Nation's waters. ${ }^{20}$ It is a milestone in marking the greater responsibility of the nation towards the environment, and has several revolutionary characteristics: firstly, it converted the conception of the 1948 FWPCA from the presumption of free discharge of water pollutants into the national waters to discharge with permission; secondly, it made a cooperative institutional arrangement under federalism, with the federal government as the primary authority and the states as the secondary; thirdly, it created a comprehensive and concrete legal mechanism, $\mathrm{NPDES}^{21}$ with detailed requirements for wastewater discharge control using technology-based standard (TBS) and water quality standard (WQS), as well as the total maximum daily loads (TMDL); at last, it is featured with a citizen suit provision in the statutory scheme for enforcement.

US CWA adopts federal-state partnership pattern. The federal government sets guidelines, objectives, and limits, and also provides technical and financial assistance to authorized 46 states (U.S. Congress, 2012) to carry out the federal law with their own monitoring, assistance, and enforcement programs. ${ }^{22}$ In China's water discharge permit system has been formed from bottom up. Thirty-one provincial-level governments have issued "Management measures for pollutants discharge permitting system" in China since 2008 Amendments of WPPCL (Su et al., 2014), while a national-wide regulation has yet been developed by the State Council, due to lack of systematic and national-wide Effluent Guidelines and the respective regulatory requirements, including the best available technology (BAT) system (Xie, 2018). US EPA identifies the best available technology that is economically achievable for that industry and sets regulatory requirements based on the performance of that technology, which represents a "spare no expense" doctrine and precautionary principle, and prescribes the acquisition of the best state of the art technology available, without regard for traditional cost-benefit analysis (Sinden. 2014).

The Effluent Guidelines do not require facilities to install the particular technology identified by EPA; however, the regulations do require facilities to achieve the regulatory standards which were developed based on a particular model technology. ${ }^{23}$ There are four levels of control technology under the NPDES, from least to most stringent, they are: Best practicable control technology currently available (BPT), Best available control technology economically

\footnotetext{
${ }^{20} 33$ U.S.C. $\$ 1251(\mathrm{a})$.

${ }^{21} 33$ U.S.C. $\$ 1342($ a), Sec. 402 CWA.

${ }^{22}$ Forty years of the Clean Water Act mean much better water,

https://www.pca.state.mn.us/about-mpca/forty-years-clean-water-act-mean-much-better-water, last visit 17 Feb. 2020.

${ }^{23}$ EPA, Learn about Effluent Guidelines, https://www.epa.gov/eg/learn-about-effluent-guidelines, last visit 17 Feb. 2020.
} 
achievable (BAT), Best conventional pollutant control technology (BCT), New Source Performance Standards (NSPS) reflecting the most stringent controls attainable through the application of the best available demonstrated control technology for all pollutants (i.e., conventional, non-conventional, and priority pollutants). BPT is the minimum standard for existing point sources of conventional, toxic, or non-conventional pollutants. If local water quality standards require more treatment, then the permitting authority may require permit applicants to install BCT (for conventional pollutants) or BAT (for toxic or non-conventional pollutants).

\subsection{The Legal Pattern of PRC WPPCL/WPDP}

When the CWA was enacted in 1972, an environmental legal framework was non-existent in China. The WPPCL is a pioneering environmental law in the legislation history of the PRC. It was enacted in 1984, five years ahead of the Environmental Protection Law (EPL). For the implementation of the WPPCL, the underlining legal mechanisms of the related regulations have evolved considerably over time from "concentration control" and "end of pipe control" to "total emission control" (TEC) and "pollution prevention", from administrative "region-based management" to "river-basin-based management", from "point source control" to "all sources control" and from "single administrative mandatory orders" to "economic and legal tools".

Currently, TEC is the leading strategy to control pollution and regulated by Art. 18 of WPPCL of 1996 and its successors. The total permissible emission of certain pollutant is determined on the national level, and the central government allocates the emission targets to provincial governments, then to city-country level governments, in the end, to industries, by use of a permitted pollutants load allocation. The TEC strategy has been proved to be useful to allow the government to make macroscopic adjustment to meet certain target, for example, the reduction of $\mathrm{CO}_{2}$ emission through promoting energy efficiency or closure of emission producers.

The role of the WPDP is on the one hand similar to the NPDES of the USA, a legal institution which creates technological requirements for pipe-end discharge, and on the other hand, is used as an instrument to support the TEC strategy. In the USA, the final elimination goal of water pollutants discharge depends on the success of the permit system, which relies heavily on TBS, the WQS and TMDL strategies are then initiated when the former fails. In contrast, China relies on TEC, because it is more easily achieved through governmental actions such as administrative order to close certain industries.

\section{Comparison of Water Pollution Control Mechanisms of Permit}

\subsection{The USA Technology Based Standard and Water Quality Standard}

The basic strategy of the CWA/NPDES is to prevent water pollution through 
technological innovation and advancement. TBSs are established to limit the discharges from point sources and demand wastewater treatment before discharged. The TBSs are determined based on a number of factors, including the available technology of different industries, the type of pollutants, the amount of pollutant production, the techniques for wastewater treatment etc. The TBSs require the EPA to determine what pollution reduction controls are available to best meet the goals, and require the industry to select the technology that best satisfies the controls. The EPA has established more than 50 sets of standards for a spectrum of industries (McGaffey, 2003). The TBSs are then incorporated into the NPDES as criteria for permits issuance of specific facilities. With that, the NPDES sets concrete and measurable limits on the amount of pollutants discharged.

The technology-based regulation is even-handed in that all members of the same industry are treated equally. Because the TBSs set minimal levels of control with which all states must comply, these standards take away incentives for industry to relocate in states with less stringent standards (Glicksman, 2009). Also, as the standards are incorporated into the NPDES, the permit compliance and enforcement are simplified: the permittee knows what is expected and regulators what is required of the various sources. The determination of violations becomes relatively simple, because each permittee must periodically file "discharge monitoring report" which allows a comparison of the discharger's actual performance with the permit requirements.

While TBS limits waste water discharge from point sources, WQS focuses on the quality of the receiving water. The considerations taken in WQS include 1) designations of the water beneficial uses; 2) water quality criteria necessary to protect the beneficial uses; and 3) anti-degradation policies. WQS is a regulatory strategy because compliance with TBS does not guarantee water quality. For waters that do not meet WQS after the application of TBS, the states are to establish TMDL and allocate the pollutant loading among the responsible sources (Andreen, 2007). WQS allows the states to 1) identify waters which fail to meet WQS despite the application of TBS; 2) target these waters by taking into account of the severity of the pollution; and 3) determine the TMDLs so that these waters meet the applicable WQS.

If the TMDL sets much stricter requirements than the TBS on the point sources, then the states must work to reduce pollution sources so that the WQS can be met, as the CWA Section 303 rules the NPDES permits must include more stringent limitations necessary to meet the WQS. Accordingly, when the TMDL is established, dischargers must comply with the more stringent permit limitations to meet the waste load allocation under the TMDL.

\subsection{The PRC Effluent Discharge Standard}

The Environmental Quality Standard for Surface Water was first published in 1983 and revised in 1988, 1999 and 2001. The quality of the water bodies was divided into five grades (Grade I has the best and V the worst water quality). For 
each grade, a WQS is specified using 24 basic pollutant concentrations and 85 other drinking-water specific items. To design the discharge standards, wastewaters are first divided into 8 major categories, including industrial, agricultural, domestic, transport, service, water-treatment, surface-runoff, and the remainder wastewaters. For each category, sub-categories are defined and for each sub-category, the MEP defines the discharge standards for a variety of pollutants. ${ }^{24}$ In practice, the discharge standards are commonly established by the MEP and the administrative authority responsible for given industries. For example, China Steel Ltd. (via Wuhan Safety Research Institute), in consultation with the MEP, established the Discharge Standard of Water Pollutants for Iron Steel Industry. ${ }^{25}$

These standards are made in accordance with the national water quality requirement and take into consideration the national economic and technical conditions, according to Article 13 of WPPCL. China's provincial governments also have the power to make their own effluent discharge standards in absence of the corresponding national standards or to make stricter standards than the national ones. Whether a discharger has complied with the standards depends on the statistics of its discharge outlet or of the outlet of processing workshop. ${ }^{26}$ In practice, local standards play a leading role in discharge permit issuance, and prevail over the national standards. If local and national standards are in conflict, the local standards often apply.

\subsection{Comparing USA Water-Quality-Based Standard with China's Total Effluent Control}

The 1988 "Interim Regulations for WPDP Management" acclaimed TEC to be the core of the permit program. In theory, permit holders should not only comply with the requirement of effluent standards but also satisfy the allocated responsibilities of effluent reduction based on the TEC strategy.

China's TEC is similarly designed as the WQS being exercised in the USA. Both of them provide the "pollutants reduction load allocation mechanism" through which the amount of pollution entering the water bodies is controlled. Under Section 303(d) of the USA CWA, states, territories, and authorized tribes are required to identify impaired waters which do not meet WQSs even after the implementation of pollution control technology. The law requires these jurisdictions to establish TMDLs for the impaired waters. An allocation of that load among the various sources of that pollutant is written into permit requirements, forming the water quality-based discharge limits. Once the TMDL is developed, the permit holders must accept the adjusted limits in accordance with the allocated reduction loads. By 2011, more than 46,000 TMDLs have been developed,

\footnotetext{
${ }^{24}$ There are 64 sets of effluent standards, made by the Department of Science, Technology, and Standard. http://kjs.mep.gov.cn/hjbhbz/bzwb/shjbh/swrwpfbz/index.htm, last visit on 12 Mai 2015.

${ }^{25}$ National Standard of the People's Republic of China, GB13456-2012, Discharge Standard of Water Pollutants for Iron and Steel Industry, published by National Environmental Protection Administration.

${ }^{26}$ Id 25, GB13456-2012.
} 
and more recent data indicate that 41,000 more water bodies still require a TMDL to initiate corrective measures. ${ }^{27}$

China's TEC strategy aims at establishing the total allowed discharge amount of pollutants within a limited region or watershed and during a limited period, taking into consideration the water quality goal and pollution assimilating capacity of the water body. It is finalized by the allocation of pollutants reduction loads among dischargers. They differ with each other in following four aspects:

1) Preconditions for TEC: In the USA, only when the water body is identified as impaired, can TMDL be initiated by the states. It is not a nationwide TEC plan, but a corrective approach to restore the quality of some waters. China's TEC is developed every five years in the national Five-Year-Plan as a political goal of the nation. It is effective for and implemented by all provinces which develop their own Five-Year-Plans and write the allocated reduction loads into their plans. The MEP examines the implementation result of each province on a half-yearly basis. ${ }^{28}$

2) Scopes of TEC: The USA TMDL targets pollutants from all sources, and accounts for uncertainties in the analysis and modeling. The controlled pollutants cover conventional, non-conventional and toxic pollutants, and for each pollutant, a TMDL plan exists. China's TEC aims to control “major pollutants" from industrial, municipal point sources and animal feeding farms. The pollutants may differ for each Five-Year-Plan. The 12th Five-Year-Plan defines only four types of pollutants for TEC (COD, $\mathrm{SO}_{2}$, ammonia-nitrogen and $\mathrm{NOX}$ ). ${ }^{29}$ TEC is thus a strategy far distant from a comprehensive water quality protection, because controlling only four pollutants is insufficient for protection of a water body, along the uncertainty inherent in any the total pollutants calculation.

3) Implementation of TEC: The USA TMDL is a pollution "budget" for a water body or watershed that establishes the pollutant reduction needed from each pollutant source to meet WQSs. ${ }^{30}$ Therefore, each TMDL plan expresses the relationship between the necessary reduction of the pollutant of concern and the attainment of the WQS. To develop a TMDL plan, states 1) select the pollutant; 2) estimate the water body's assimilative capacity; 3) define all sources; 4) make a predictive analysis and determine the total allowable pollution load; and 5) allocate the allowable pollution among the different pollution sources so that WQS is achieved. ${ }^{31}$ TMDL takes into consideration the seasonal variation of a water body and accounts for the different requirements for the dry and wet seasons. Several comments are appropriate. Different from USA TMDL, China's TEC is

${ }^{27}$ http://water.epa.gov/learn/training/standardsacademy/upload/module_tmdl.pdf, last visit on 12 May 2015.

${ }^{28}$ MEP (24 Sep 2014): "Bulletin about the amount of effluents discharge in each province, autonomous region and municipal city during the first half year".

http://www.mep.gov.cn/gkml/hbb/qt/201409/t20140924_289464.htm, last visit on 12 May 2015.

${ }^{29}$ MEP (Dec.2011): Rules for the Total Effluent Reduction Calculation of 12th Five-Year-Plan. http://www.mep.gov.cn/gkml/hbb/bwj/201206/W020121012519874173523.pdf, last visit 12 May 2015.

${ }^{30} \mathrm{http}: / /$ dnr.wi.gov/topic/tmdls/tmdlprocess.html, last visit 12 May 2015.

${ }^{31} \mathrm{http} / / /$ water.epa.gov/lawsregs/lawsguidance/cwa/tmdl/dec3.cfm, last visit 12 May 2015. 
firstly made according to the different social-economic status and hydrological conditions of the eastern, central and western regions of China. The total permissible waste load is not decided by rigorous scientific analysis of the water bodies, but by political intent and public concern. ${ }^{32}$ Second, the TEC targets are determined every five years. In such a long period, pollutants accumulation, pollution sources, water purification capacity and water mass vary significantly and affect the adequacy of the TEC target. Third, the permitted amount of discharge is first allocated among provinces, then among city-county level regions, and finally among the discharge entities, in the form of "total allowed discharge concentration", or "total allowed discharge speed" or "total allowed discharge amount of unit product" (Song, 2000). Then, the permit holders are requested to comply with the minimum level of effluent standard requirement and the pollutants reduction requirement. There is however no legal document for explanation of their relationship. Forth, unlike TMDL, China currently uses a total yearly load even five year load control.

4) Public participation into TEC: Once initiated, the TMDL will be integrated into the USA CWA/NPDES, public has access to the reports about the implementation of it, such as Chesapeake Bay TMDL case (Copeland, 2012). In comparison, China's WPPCL regulates to react to the local governments and dischargers that did not meet the load reduction goals by "publishing their names" on the web of MEP. The named entities must take corrective actions under MEP's supervision. This is another way of public participation, not at the same time with implementation but after the failure of it.

The functioning of the TEC strategy is as illustrated in Figure 1. The MEP establishes the WQSs for waters to be achieved by TEC through discharge allocation and discharge standards. But according to the WPPCL, technological and

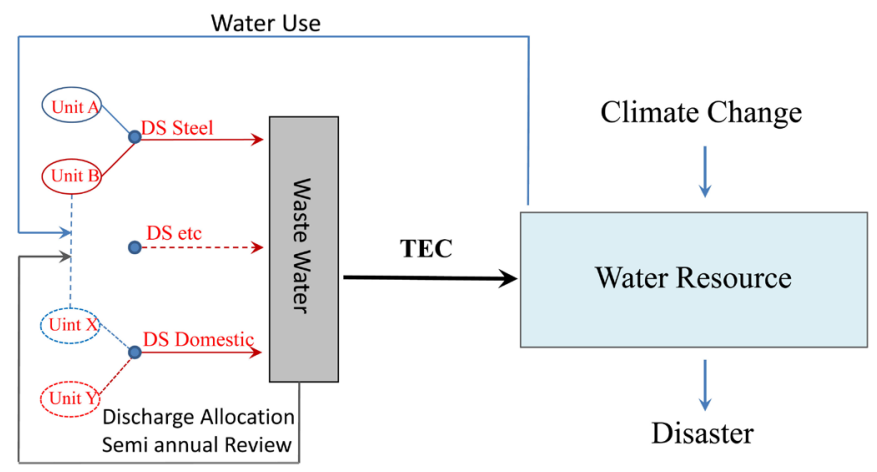

Figure 1. An illustration of the institution of China's WPDP system. MEP establishes the environment water quality standards. The standards are to be achieved by TEC. The total waste load is then allocated to discharging units. The standards of discharged waters are defined by the MEP in consultation with industries, and the discharge permits are issued by local EPB. MEP conducts semi-annual reviews of major dischargers. Due to climate change, water levels vary. During low waters, the same TEC strategy may result in water quality disaster.

${ }^{32}$ MEP (20 Aug 2009): Seeking for a new model for Total Pollutants Control of $12^{\text {th }}$ Five-Year-Plan. Important Environmental Information Reference 5-11, p18. 
economic conditions of the country must be taken into consideration, so the industries can contribute to the development of discharge standards. The discharge permits are issued by the local EPBs at city-county level to the individual dischargers.

This is a complex model with considerable potential of failure, because the total emission of pollutants becomes uncontrollable if the discharge standards are inadequate and violated. Although China has already published a large set of discharge standards, explicit information as to how they are designed is not publically available. The risk of the TEC strategy can be illustrated using a simple analysis. As Chapra (2008) explains (Chapra, 2008) the accumulation for pollutant (e.g. COD) in a water body is given by:

$$
\text { A }(\text { Accumulation })=P(\text { Pollutant Discharge })-R \text { (Purification })
$$

where $\mathrm{P}$ equals the discharged wastewater times the concentration of that water $\mathrm{Cd}$, and $\mathrm{A}$ equals the waterbody mass $\mathrm{M}$ times the pollution concentration of the waterbody C. C is steady if discharge equals purification, $\mathrm{P}=\mathrm{R}$. If $\mathrm{P}$ is larger than $\mathrm{R}$, then $\mathrm{C}$ increases and water quality deteriorates. Even for this simple case, using $\mathrm{C}$ (concentration-based water quality standard) to determine $\mathrm{Cd}$ (concentration-based discharge standard) is problematic if $\mathrm{R}$ is unknown. $\mathrm{C}$ also depends on $\mathrm{M}$ (or the water pollution carrying capacity). In times of low water levels, $\mathrm{C}$ is poorer for the same discharge. Thus, during low waters, $\mathrm{C}$ can be large and pollution disasters more likely.

While the application of TMDL strategy requires sophisticated water management capability, as the major setbacks of its implementation in the USA and decades of legal battles and controversies suggest (May, 2004, 2005), the application of the TEC strategy is even more difficult. It is extremely difficult to estimate the required total emission on national scales. The pollutants purification capacity $(R)$, the pollutants carrying capacity $(M)$ and the demand for discharge of polluted water $(\mathrm{P})$ must be known on basin scales. While $\mathrm{R}$ involves complex bio-geochemical processes and $\mathrm{M}$, hydro-climatological processes, $\mathrm{P}$ involves social-economic activities, making the estimate of TEC a formidable task. The TEC strategy is particularly risky if the permit system is not well monitored and enforced. If the monitoring is limited to the quality of discharged water, and not the daily load, then the TEC target is vulnerable. More recently, China has invested heavily in building up the water quality monitoring network and the MEP has commissioned the "Major Science and Technology Program for Water Pollution Control and Treatment" ${ }^{\prime 3}$, so that implementing a TMDL within the WPDP may be possible in the near future.

\section{Permit Compliance and Legal Enforcement in the USA and in China}

In the USA and China, the permit compliance and legal enforcement relies primarily on the administrative action. That is proved to be the most quick and ef-

${ }^{33}$ http://nwpcp.mep.gov.cn, last visit May 122015 . 
ficient government response to permit violations. Difference is the level of public access interfered with.

\subsection{Compliance and Enforcement of Permit in the CWA}

The CWA is supported by a compliance/enforcement scheme within the general framework of the environmental law enforcement. The concept of "environmental justice" is a widely accepted premise and the moral basis of environmental law enforcement in the USA. It has also been one of the EPA's top priorities to integrate environmental justice into compliance/enforcement programs and program-implementations (Cory et al., 2012).

The USA EPA employs an array of tools to achieve law compliance, including monitoring, investigation, administrative and judicial actions, as well as compliance assistance and incentives. These tools balance compliance through provision of guidance/assistance and violation correction by imposition of penalties and legal actions. In practice, the EPA takes a pragmatic approach with its compliance/enforcement programs relying more on pollution control technologies and focusing judicial actions on cases that are expected to result in large environmental benefits.

The EPA and the delegated states are empowered by the CWA to take enforcement actions (Earnhart \& Glicksman, 2006). The CWA Section $309^{34}$ rules that the primary enforcement options for the EPA include issuing administrative compliance orders, assessing administrative penalties, referring civil cases for penalties and criminal cases for prosecution. ${ }^{35}$ In practice, the USA EPA takes tough civil and criminal enforcement actions against violators only as the last option. Most CWA/NPDES violations are dealt with and settled through Administrative Enforcement Actions. An administrative enforcement action either 1) requires violator to take action to comply, 2) revokes permit, 3) imposes penalties or 4) supplements environment projects. Most administrative enforcement actions lead to either consent agreements or administrative orders.

The most frequent enforcement action is administrative penalty. In 2013, the EPA processed 1440 final administrative penalty orders and referred 138 civil cases to the USA DOJ; it was reported the assessment of nearly $\$ 1.15$ billion in civil penalties and $\$ 4.5$ billion in combined criminal fines, restitution, and court-ordered environmental projects (Esworthy, 2014). However, the CWA compliance/enforcement scheme has also shown deficiencies. At the present, about $50 \%$ of the NPDES (small-individual) permit holders violate the permit requirements. The overall effectiveness of the compliance/enforcement strategy of the EPA is now of considerable concern.

Environment law enforcement in the USA operates within a complex framework and organizational setting. While the laws and regulations involve federal and state regulators and the regulated community. The regulated community covers industrial and non-industrial entities, federal facilities, state

${ }^{34} 33$ U.S.C. $\$ 1319$.

${ }^{35}$ http://www2.epa.gov/enforcement/water-enforcement. Last visit 23 Jul 2015. 
and local governments, etc. Figure 2 depicts the USA environmental law compliance/enforcement framework and the key players. In case of the CWA, the states assume primary enforcement responsibilities and conduct a large proportion of inspections and enforcement actions. Citizens have standings to raise a lawsuit against government that has neglect of duty or polluters. They identify and report violations, comment on enforcement cases and initiate enforcement proceedings against violations; bring actions against the federal or state EPA for non-diligence. Citizens can lodge online complaints, and assist in locating alleged environmental criminal fugitives.

Civil cases are a large component of the enforcement actions, second only to administrative cases. They are lawsuits filed in court against permit holders for alleged violation of permit requirements or administrative orders. As with administrative cases, most civil cases lead to a consent decree. The CWA authorizes criminal enforcement actions against individuals or entities who negligently or deliberately violate the statute. The criminal enforcement scheme includes imprisonment, monetary penalties, or both.

Citizen enforcement is indispensable to the CWA enforcement. Citizens are empowered to act as "Private Attorney Generals" to enforce compliance (Morrison, 2005). In particular, the CWA Section 505 states that any person has the right to commence a civil action on his own behalf against either 1) any person who violates an effluent standard or limitation, or 2) the EPA for failure to perform any act or duty... which is not discretionary. ${ }^{36}$

The first issue concerning citizen action is the citizen legal standing. To have an individual standing, citizens must show that 1) they have suffered an injury in fact that is concrete and particularized, actual and imminent; 2) the injury is traceable to the defendant's challenge action; and 3) it is likely that the injury will be redressed by a favorable court decision. Plaintiffs need not establish the causal connection with absolute scientific rigor. Citizen claimants need not show prudential standing. Citizens are also empowered to act against the EPA if it fails to perform nondiscretionary act or duty. Citizen suits are also important to develop new regulatory programs and to improve existing regulatory programs.

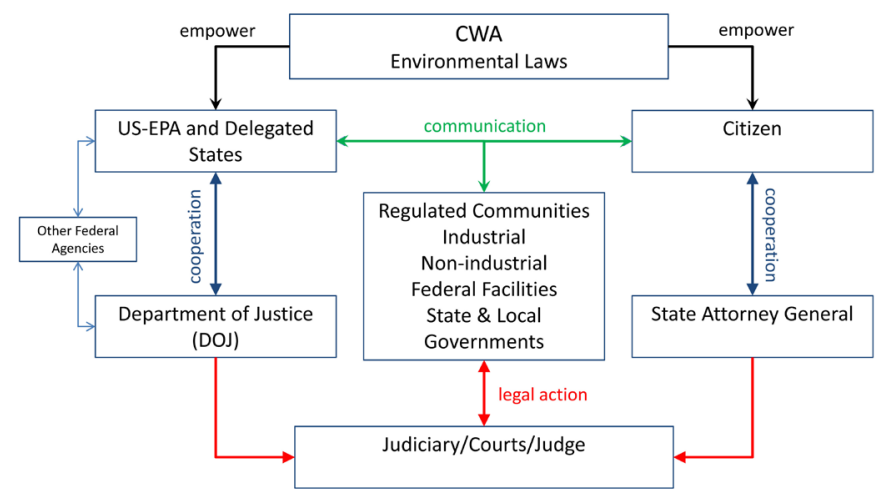

Figure 2. The basic USA environmental law compliance/enforcement framework and organizational setting.

${ }^{36} 33$ U.S.C. $\$ 1365(a)$. 


\subsection{Compliance Instrument and Legal Enforcement Mechanism of WPPCL of China}

According to Ma \& Zhou (2012), because of the large discrepancy between the water quality standard and the low water pollutants discharge standard, the industries only need to pay a low fee for wastewater treatment to achieve an economic benefit of 200 billion CNY p.a. The authors estimated that the total industrial water use in China in 2009 was 73.2 billion $/ \mathrm{m}^{3}$. Most Chinese industries take natural water of Category III, and discharge back to the same natural water after treatment. The subsidized water cost of industrial water use (resource fee + discharge fee) is $0.26 \mathrm{CNY} / \mathrm{m}^{3}$, while the actual cost is $2.16 \mathrm{CNY} / \mathrm{m}^{3}$. Thus, the industry makes an economic profit of $1.9 \mathrm{CNY} / \mathrm{m}^{3}$. This practice sacrifices water quality for economic gain, contradicting the WPPCL objectives (Ma \& Zhou, 2012).

Due to such fundamental contradictions, the Chinese government is handicapped to enforce the WPPCL. The enforcement actions are mostly visible in cases of severe water pollution accidents. A more interesting form of the enforcement is that the Chinese government actually shoulders much of the responsibilities of water pollution. During the periods of the 10th and 11th Five Year Plan, the Chinese government spent 180 billion CNY for water pollution settlement (Ma \& Zhou, 2012).

The conflict between China's desire for economic growth and environment protection is clearly reflected in the Taihu case. Taihu is the 3rd largest lake in China and the Taihu basin is economically highly developed. In 2007, the basin has a GDP of 2865 billion CYN, ${ }^{37}$ but depended strongly on heavy pollution industries. As the economy flourished, the water quality worsened. From the 1980s to the 2000s, the water quality of Taihu dropped from Grade II to III to Grade IV to $\mathrm{V}$ and in the five years prior to 2007 , it was consecutively Grade V. In 2007, Taihu experienced the worst eutrophication outbreak in history.

To combat the problem, the government took highly publicized actions. The well known example is the "Taihu Zero Action" in 1999 (Sun, 2003). The State Council jointly with the relevant provinces launched a massive clean-water campaign in the 1990s with an ambitious goal of "Taihu Clean Water" by 2000. The campaign reached its climax in 1998. The action was claimed to be a major success, i.e. by 0:00 on 1 Jan 1999 all key sources of waste water discharged to Taihu, comprising 1035 enterprises, had met the standard. However, the water quality of Taihu continued to deteriorate. In the 1990s, the wastewater discharges into Taihu was estimated to be $860 \mathrm{Mt}$ per year. By 2000, it was a massive $5.33 \mathrm{Gt}$ (Qin, 2008).

A similar campaign was repeated in 2006, the so-called "Three Chemical Remediation Action", to renovate small chemical plants. However, by the time of the 2007 eutrophication outbreak, the government was unable to close a single chemical plant. In 2008, the Jiangsu provincial government imposed for the

${ }^{37}$ Management Bureau of Taihu Lake Basin (2008): Environment Status Report of Taihu Lake. 
Taihu Basin the most stringent discharge standard in China for water treatment facilities, ${ }^{38}$ established new wastewater treatment facilities and upgraded existing wastewater treatment facilities. The impact of this campaign is yet to be fully examined.

The WPPCL/WPDP enforcement depends on its relationship to other laws of the nation, including the constitutional law which defines the environmental protection duty of the nation and the environmental rights of the citizens, and the civil and criminal laws which define the civil liability and criminal punishment for water pollution and the administration law based on which governments process tasks.

The General Principles of Civil Law states that "Any person who pollutes the environment ... shall bear civil liability." ${ }^{39}$ The Tort Liability Law ${ }^{40}$ further concretes the tort liability of polluters. In 2001, the Supreme People's Court adopted Several Provisions on Evidence of Civil Litigation. ${ }^{41}$ They provided that if the injured takes action against the suspected polluter, then the latter shall bear the burden to prove or otherwise the causation between the damage and the action. On this basis, dischargers of pollutants are burdened by the WPPCL (Art. 98) for their exemption and no causality between their activities and damages. The proof of fault or intention when imposing environmental civil liabilities is not required. This strict liability discipline is the same as in the USA.

China's Criminal Law (1997) defines environmental pollution as a crime (Articles 338-346). The 2011 Amendments to this law lowered the threshold of the incrimination. ${ }^{42,43,44}$ But there were only 11 environmental criminal cases in 2010, compared to 694 administrative review cases and 116,820 administrative penalty cases. ${ }^{45}$ In 2011, 2012 and 2013, no criminal case was reported as all environmental cases were dealt with through administrative measures and/or penalties. ${ }^{46}$ This shows that in China, administrative measures are preferred to deal with the possible violations of the environmental laws, other than to legal procedures. As a result, the criminal law has so far played little role in environmental protection in China.

During 2000-2013, there were about 60 lawsuits raised by environmental public interest groups in China. In 2013, the High-Level Court of Guizhou Province

\footnotetext{
${ }^{38}$ Jiangsu Province Environmental Protection Bureau (2007): Discharge Standard of Main Water Pollutants for Municipal Wastewater Treatment Plant \& Key Industries of Taihu Area. Adopted 8 Jul 2007; Effective since 1 Jan 2008.

${ }^{39}$ NPC (1986): Article 124 of The General Principles of the Civil Law of the People's Republic of China.

${ }^{40}$ Standing Committee of NPC (2009): The Tort Liability Law of the People's Republic of China; Promulgated in 2009; Effective in 2010. Art. 65-68 specialize the tort liability of polluters.

${ }^{41}$ Supreme People's Court of the PRC (6 Dec 2001): Some Provisions of the Supreme People's Court on Evidence in Civil Procedures. Promulgated on 6 Dec 2001; Implemented on 1 Apr 2002. No. 33 of [2001].

${ }^{42}$ The Criminal Law of the People's Republic of China (1997), Article 338.

${ }^{43}$ The Criminal Law of the People's Republic of China (2011), Article 338.

${ }^{44}$ http://www.npc.gov.cn/npc/xinwen/2011-02/25/content_1625679.htm.

${ }^{45}$ National Bulletin on Environmental Statistics (2010), http://zls.mep.gov.cn/hjtj/.

${ }^{46}$ National Bulletin on Environmental Statistics but for 2011, 2012 and 2013.
} 
reported that less than $1 \%$ of the environmental disputes could be dealt through the court system, about $0.4 \%$ of all legal cases in that province (Wang et al., 2014). The obstacles for the lack of court activities are 1) complex requirements for a civil public interests litigation; 2) difficulty in collecting evidence; 3) high cost of expert testimony; and 4) high probability of losing.

The enforcement actions in China appear to be weak to protect citizens from environmental harm. According to the law, an effluent discharger must have a permit. But pollution discharge without permit, non-compliance with permit requirements and non-renewal of expired permit are so widely spread that local governments often ignore them. Most polluters prefer to pay the small penalty rather than to stop illegal discharges. For example, it was exposed in 2015 that the Huaxing Pharmaceutical Factory directly discharged waste gases and water. This state-owned company ended up with only having to pay the administrative penalties.

China's legislators have struggled for a long time to define whether NGOs have standing to raise environmental lawsuit. The WPPCL side stepped defining the standing, as its Article 99 regulates that local EPBs and social organizations could "support" pollution injurers to raise a lawsuit, and the legal service institutions and lawyers are "encouraged" to provide "legal assistance" for the persons who are suffering from water pollution. The first clarification can be seen in Article 55 of the Civil Procedural Law of PRC (2012), which stipulates that activities leading to environmental pollution and harm of public interests could be prosecuted by authorized agencies or related organizations. The interpretation for "authorized agencies or related organizations" is up to court's discretion. In 2013, the All-China Environment Federation has brought as plaintiff eight litigations, but all were refused to be heard by the courts with the reason of no standing (Zhao, 2014). Until 2015, the EPL clearly allows an NGO to file litigation under the following conditions: 1 ) it is registered at a municipal level or higher level government; 2) it is engaged in activities for environmental protection for 5 years or more and has no law violation records; and 3) it does not seek economic benefits from litigation. ${ }^{47}$ In 2015, the All-China Environment Federation raised two civil litigations, both accepted for hearing. But in the Environmental Protection Federation of Taizhou vs. Chang Long Chemical Engineer Company case (2014, Middle-Level Court of Taizhou), the defendant questioned the plaintiff's standing, because it was founded for only two years, according to the draft of EPL, only NGO with more than 5 years experiences could have standing. Court recognized the Environmental Protection Federation of Taizhou as a qualified plaintiff, according to the Civil Procedural Law, and decided a penalty of 160 million CNY on the defendant for water environmental compensation and reparation. The EPL 2015 has set more stringent requirements for NGOs than Civil Procedural Law 2012.

Governmental enforcement action is the primary mechanism for WPPCL/WPDP enforcement. The government enforcement actions of the WPPCL/WPDP are

${ }^{47}$ The Environmental Protection Law of the People's Republic of China (2015), Article 58. 
mostly in the form of administrative penalties including:

Temporary closure and safety checks of the particular polluting facility; Fines on the polluters; Temporary demotion or transfer of the responsible administrators; Punishment of EPB officers.

The characteristics of this type of enforcement are clearly seen in the Nov. 2005 severe water pollution case of the Songhua River. Only in rare cases, the criminal law is invoked and imprisonment of polluters followed. The framework and organizational setting for environmental law enforcement in China, including the WPPCL, are illustrated in Figure 3.

\section{Summary and Recommendations}

Using the referential method, we carried out a comparative study on the USA CWA and the PRC WPPCL. Both laws are designed in response to water pollution problems in the respective countries, and both employ a discharge permit system as a vehicle to achieve the environmental management goals. However, while the CWA/NPDES has enjoyed much success in improving the water quality of the USA, the WPPCL/WPDP has not been able to curb the trend of increased water pollution in China. Then, what are the reasons?

Our study shows that substantial differences exist between the USA CWA/NPDES and the PRC WPPCL/WPDP. The results of the comparison can be summary from the following perspectives:

1) Objectives of the laws: the CWA aims to restore and maintain the chemical, physical, and biological integrity of the waters, while the WPPCL aims to balance economic development and environmental protection. The objective of the CWA places water integrity high on the national agenda and reflects the ethical premise of clean water. In contrast, the WPPCL retains economic development as the highest national agenda and water quality protection secondary. As a result, although the WPPCL provides a legal basis for water quality protection in

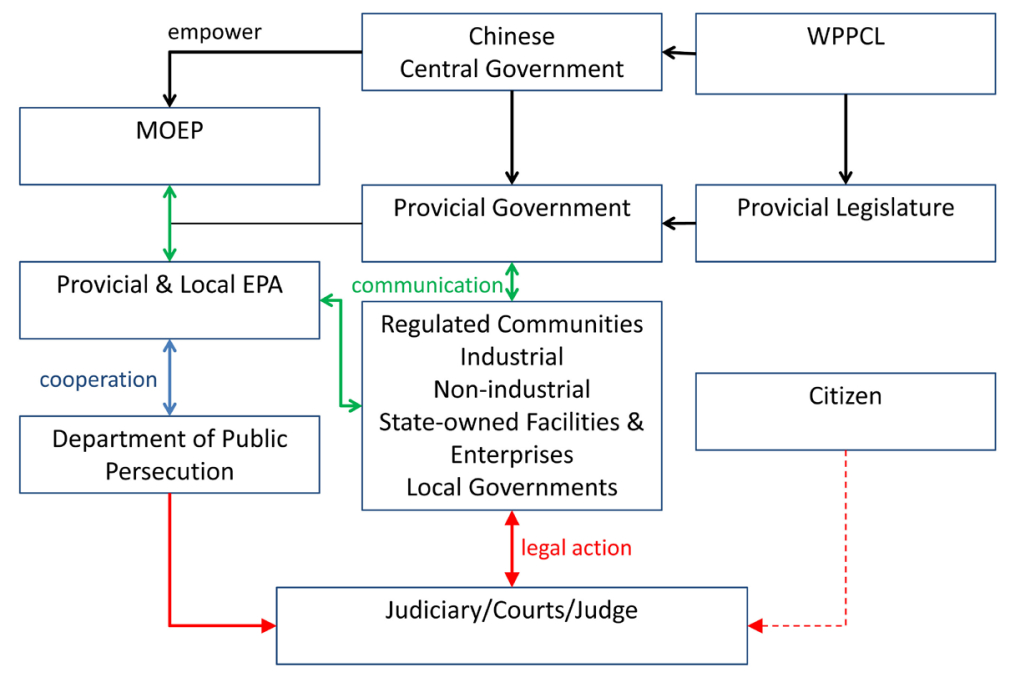

Figure 3. The basic Chinese environmental law compliance/enforcement framework and organizational setting. 
China, it at the same time provides an implicit justification of economic development at the expense of water quality. The water pollution levels China experienced in recent years demonstrate that the destructive powers of the economy to the water integrity are much beyond the jurisdiction of the WPPCL.

2) Roles of the laws: The roles the laws play in the two countries also differ. While the CWA/NPDES plays a central role in the USA, the WPPCL/WPDP is in general supportive. The most noticeable results in water pollution control achieved in China so far cannot be attributed to the law but to the political decisions of the government and the direct investment by the government to develop the water treatment facilities. These measures do not necessarily make use of the law. Changes in government policies can achieve quick results, but they are often ad-hoc and inconsistent.

3) Jurisdiction: The CWA has a broad scope of jurisdiction, i.e., it extensively defines all waters of the USA are protected by the law, while the WPPCL is more specific and dedicated primarily to drinking water safety and then to industrial and municipal wastewater control. The legislation procedures in the USA and China are also very different. The CWA is a detailed law, further concretized via the NPDES to be directly executable and enforceable. By doing so, the NPDES becomes an integral part of the law. In contrast, the WPPCL only stipulates the principles and its implementation are realized via the regulations of the State Council, which until now are still in preparation. The legislation and implementation are thus not an integral part and consequently, although the WPPCL was amended in 2008, it remains to be properly implemented. The legislation-implementation process in China is further complicated, because the WPPCL can also be interpreted by the provincial legislative bodies, and the provincial governments need to respond to these interpretations and develop the corresponding regulations for implementation. So far, the WPDP is implemented based on the regulations of local governments. This process separates the law from implementation and generates a large degree of variations. The outcome in the reality becomes very different from what the law is supposed to achieve.

4) Implementation: On the technical level, the NPDES employs a dual-standard system. TBS has proved to be very successful, but WQS, despite its potential, has not produced convincing results. Interestingly, China's TEC strategy is more similar to the WQS approach, and the WPDP becomes merely a method for discharge allocation. The TEC strategy has large risks of failure if the WPDP is not checked by maximum loading. TBSs also exist in China, but they give permissive conditions for water pollutant discharge.

5) Enforcement: Both the CWA/NPDES and the WPPCL/WPDP in theory employ administrative, civil and criminal enforcement measures. The CWA/NPDES relies heavily on administrative and civil and rarely on criminal enforcement actions. The enforcement of WPPCL/WPDP relies primarily on administrative measures and administrative fines, which bypass civil and criminal legal actions. The administrative fines are mostly much lower than the cost needed for WPDP 
compliance. This practically encourages permit holders to discharge pollutants without compliance. There have been very few cases of criminal enforcement actions against direct polluters in China, but quite a few cases against local EPB's officers for non-diligence of duty.

Several recommendations can be to better design and implement the WPPCL/WPDP in China: ${ }^{48}$

1) Ethical Premise: China should promote its traditional ethical premise of "nature-human harmony" and the new ethical premise that "water must be clean". The economic factor should no longer serve as the dominant consideration for the social welfare and people's happiness. This ethical premise is now increasingly realized in China and the request of the people for a better environment is becoming stronger. Thus, the objective of the WPPCL should no longer be the "balance" between economic development and environment protection, but the protection of water quality. Only by doing so, environmental protection can be placed among the highest priorities in the national agenda.

2) Concrete Law: The WPPCL only stipulates the principles while its implementation is done through regulations at various administrative levels. The disjunction between the law and practice has the unusual consequence, that after eight years of its enactment (in 2008), the WPPCL is still waiting for regulations for its full implementation. Given China's reality, embedded in the regulations are the priorities of the governments, which are not always consistent with the original purpose of the law. It is thus desirable for the NPC to legislate concrete environmental laws that are directly implementable and are subject only to supplementary regulations, rather than heavy reliance on regulations.

3) Discharge Standards: The main function of China's WPDP is to allocate the pollution discharge load to enterprises to serve the TEC strategy which has inherent risks. The dual-standard system of the USA functions better. In particular, the TBS has proven to be very successful, and the TMDL technique is necessary for the WQS to work, although the implementation of TMDL encountered considerable difficulties. China's WPPCL/WDPD should adopt in future the dual standard approach. The law should authorize the MEP to establish TBS and to introduce TMDL to secure the effective implementation of WQS.

4) Enforcement: A weakness of China's WPPCL/WPDP is the law enforcement. There are contradictory demands in the society, some enhance while others weaken the enforcement. The enforcement of the WPPCL/WPDP employs in theory administrative, civil and criminal enforcement, but in practice its enforcement relies primarily on administrative measures which bypass all other legal actions. Therefore, in addition to the administrative measures, China should activate its entire legal system to enforce environmental laws. The law should authorize citizens to participate in law enforcement. Citizens should enjoy access to freedom of information and the right to take legal actions against

${ }^{48}$ China's environmental legal framework has been evolving at a fast pace in the past few years. The authors have observed that some of the recommendations made in this thesis are fully consistent with the new developments in China. 
alleged polluters and duty-negligent administrative bodies. Finally, the law should promote the culture of cooperative responsibility and allow for incentives for the regulated community to comply with the law.

\section{Funding}

This paper is supported by the "Fundamental Research Funds for the Central Universities, Hohai University", as part of the Project "Research on the Rights and Responsibilities of Governments, Enterprises and citizens in the New Environmental Legal System-from the Perspective of the Sewage Permit System”.

\section{Conflicts of Interest}

The authors declare no conflicts of interest regarding the publication of this paper.

\section{References}

Andreen, W. (2008). Delegated Federalism versus Devolution: Some Insights from the History of Water Pollution Control. In W. Buzbee (Ed.), Preemption Choice: The Theory, Law, and Reality of Federalism's Core Question (pp. 257-276). Cambridge: Cambridge University Press. https://doi.org/10.1017/CBO9780511552007.013

Andreen, W. L. (2007). Motivating Enforcement: Institutional Culture and the Clean Water Act. Pace Environmental Law Review, 24, 67. https://ssrn.com/abstract=985121

Chapra, S. C. (2008). Surface Water Quality Modeling, Lecture 1, Introduction (pp. 13). Long Grove, IL: Waveland Press Inc.

Copeland, C. (2012). Clean Water Act and Pollutant Total Maximum Daily Loads (TMDLs). Congressional Research Service Report for Congress. Washington DC: Congressional Research Service, Library of Congress. https://digital.library.unt.edu/ark:/67531/metadc276865/

Cory, D. C., Rahman, T., Aradhyula, S., Burns, M., \& Kiger, M. H. (2012). Federal register of environmental documents: Executive Order 13132-Federalism. In Environmental Justice and Federalism. Cheltenham, UK: Edward Elgar Publishing. https://doi.org/10.4337/9781781001400

Davison, S. (2005). Defining “Addition" of a Pollutant Into Navigable Waters from a Point Source Under the Clean Water Act: The Questions Answered-and Those Not Answered-By South Florida Water Management District vs. Miccosukee Tribe of Indians. Fordham Environmental Law Review, 16, No. 1. http://ir.lawnet.fordham.edu/elr

Earnhart, D., \& Glicksman, R. L. (2006). The Comparative Effectiveness of Government Interventions on Environmental Performance in the Chemical Industry. Stanford Environmental Law Journal, 26, 317-332. https://ssrn.com/abstract=944828

Esworthy, R. (2014). Federal Pollution Control Laws: How Are They Enforced? Congressional Research Service. https://fas.org/sgp/crs/misc/RL34384.pdf

Glicksman, R. L. (2009). The Advantages of Technology-Based Standards in Protecting Health, Safety, and the Environment. http://www.progressivereform.org/perspstatutory.cfm

Griffiths, C., Klemick, H., Massey, M., Moore, C., Newbold, S., Simpson, D., Walsh, P., \& 
Wheeler, W. (2012). U.S. Environmental Protection Agency Valuation of Surface Water Quality Improvements. Review of Environmental Economics and Policy, 6, 130-146. https://doi.org/10.1093/reep/rer025

Griggs, B. W., Peck, J. C., \& Xue, Y. P. (2009). Comparative Water Law and Management: The Yellow River Basin in Western China and the State of Kansas in the Western United States. Kansas Journal of Law \& Pubic Policy, 18, 428-461.

https://ssrn.com/abstract=1491226

Junker, K. W. (2014). A Focus on Comparison in Comparative Law. Duquesne Law Review, 52, 69-99.

Kapp, R. W. (2014). Clean Water Act (CWA). US. Encyclopedia of Toxicology (3rd ed., pp. 979-981). https://doi.org/10.1016/B978-0-12-386454-3.00830-7

Ma, Z., \& Zhou F. (2012). The Status Quo of China's Water Price Policy and Its Countermeasures.

May, J. (2004). The Rise and Repose of Assimilation-Based Water Quality, Part I: TMDL Litigation). Environmental Law Reporter, 34, 10247-10260.

https://ssrn.com/abstract $=1333856$

May, J. (2005). The Aftermath of TMDL Litigation: Consent Decrees and Settlement Agreements (October 26, 2005). Clean Water Act: Law and Regulation, ALI-ABA, 2005. https://ssrn.com/abstract $=1475422$ https://doi.org/10.2139/ssrn.1689156

McGaffey, K. M. (2003). Water Pollution Control under the National Pollutant Discharge Elimination System. In M. Ryan (Ed.), The Clean Water Act Handbook (2nd ed.). Chicago, IL: Section of Environment, Energy, and Resources, American Bar Association.

Mims, A. L. (2015). Discharge of a Pollutant: The Clean Water Act Definition That Has Caused MUCH Confusion. Journal of Environmental and Sustainability Law, 20, 179-201. https://scholarship.law.missouri.edu/jesl/vol20/iss2/7

Morrison, T. W. (2005). Private Attorneys General and the First Amendment. Michigan Law Review, 103, 589. https://repository.law.umich.edu/mlr/vol103/iss4/1

Qin, B. Q. (2008). Taihu Lake, China: Dynamics and Environmental Change. Berlin: Springer. https://doi.org/10.1007/978-1-4020-8555-0

Reimann, M., \& Zimmermann, R. (2006). The Oxford Handbook of Comparative Law. Oxford: Oxford University Press. https://doi.org/10.1093/oxfordhb/9780199296064.001.0001

Sinden, A. (2014). Cost-Benefit Analysis, Ben Franklin, and the Supreme Court. UC Irvine Law Review, 4, 1175. https://scholarship.law.uci.edu/ucilr/vol4/iss4/4

Song, G. J. (2000). China's Total Emission Control and Concentration Control Systems. Environmental Protection Journal, No. 6, 11-13.

Su, D., Wang, X., Li, Z. Y., \& Hu, C. (2014). Analysis and Perfection of Pollutant Discharge Permitting System of Each Province in China. Environmental Pollution \& Control, 36, 84+91-96.

Sun, W. H. (2003). Comparative Analysis of Water Quality of Taihu Lake around "Zero-Point Action”. Jiangsu Environmental Science and Technology, 16, 35-36.

U.S. House of Representatives, Committee on Transportation Infrastructure, U.S. Congress (2012). Forty Years after the Clean Water Act: Is It Time for the States to Implement Section 404 Permitting?: Hearing before the Subcommittee on Water Resources and Environment of the Committee on Transportation and Infrastructure, House of Representatives, One Hundred Twelfth Congress, Second Session (pp. 76-147). Wash- 
ington DC: Government Printing Office.

Vicario, L., \& Ohliger T. (2015). The United States Environmental Policy Update. Indepth Analisis for ENVI Committee. http://www.europarl.europa.eu/studies

Wang, L., Yan, Q., Li, F., \& Hu, X. (2014). It Is Difficult To Raise An Environmental Lawsuit Needs To Be Changed. Economic Information.

http://dz.jjckb.cn/www/pages/webpage2009/html/2014-10/08/content_96327.htm?div= $\underline{-1}$

Xie, W. (2018). Research on the Implementation of China's Pollutant Discharge Permit. Legal Forum, 33, 105-114.

Zhao, Y. L. (2014). Last Year, All of Public Interests Litigation Raised by the All-China Environment Federation Were Refused. China Youth Daily. http://zqb.cyol.com/html/2014-04/04/nw.D110000zgqnb_20140404_3-05.htm

Zweigert, K., \& Koetz, H. (1998). An Introduction to Comparative Law (3rd ed., Translated by Tony Weir). Oxford: Oxford University Press. 